\title{
DEGRADASI LAHAN PADA KEBUN CAMPURAN DAN TEGALAN DI KABUPATEN DHARMASRAYA
}

\author{
Syafrimen Yasin, Gusnidar, Dedy Iskandar \\ J urusan Tanah F akultas Pertanian U nand Padang
}

\begin{abstract}
Abtract
Penelitian ini telah dilaksanakan di Kecamatan Sungai Rumbai Kabupaten Dharmasraya dan Laboratorium Jurusan Tanah Fakultas Pertanian Universitas Andalas. Tujuannya adalah untuk melihat status kesuburan tanah pada lapisan bawah $(0-20 \mathrm{~cm})$ pada berbagai jenis penggunaan lahan, khususnya pada kebun campuran dan tegalan.

Pengambilan sampel tanah diambil pada kelerengan 0 sampai 8\% (datar sampai berombak) dengan tanah jenis Ultisol. Jenis penggunaan lahan yang diteliti adalah hutan, Tegalan, Semak belukar, Alang-alang, dan Kebun campuran. Sampel tanah komposit untuk analisis kimia, diambil pada kedalaman 0-20 cm sebanyak empat ulangan (sub sampel) pada tiap ulangan dilakukan lima kali pemboran. Sampel tanah utuh diambil dengan ring sampel dengan empat ulangan untuk analisis berat volume. Data dari hasil analisis tanah uji secara kriteria dan statistik dengan Anova dan dilanjutkan dengan uji Beda Nyata Terkecil (BNT) pada taraf nyata $5 \%$.

Dari hasil penelitian tersebut dapat disimpulkan bahwa penggunaan lahan kebun campuran memiliki kandungan C-organik lebih tinggi dan BV tanah lebih rendah dibandingkan dengan lahan tegalan.
\end{abstract}

\section{Key Words: Degradasi Lahan, Kebun Campuran, Tegalan}

\section{PENDAHULUAN}

Pembukaan hutan besar-besaran di Kabupaten Dharmasraya, baik untuk peruntukan transmigrasi (lahan pekarangan, pangan, dan perkebunan), maupun untuk dijadi-kan perkebunan dengan berbagai jenis tanaman industri telah mengakibatkan perubahan fungsi lahan. Dengan telah terjadinya perubahan fungsi hutan ke berbagai penggunaan tersebut, tentu juga akan terjadi perbedaan dalam penurunan tingkat kesuburan tanah (degradasi lahan).

Ekosistim hutan alami khususnya di daerah tropika diyakini merupakan ekosistim yang mempunyai siklus tertutup, dan merupakan suatu bentuk ekosistim yang berkelanjutan atau sustainable. Oleh karenanya ekosistim hutan alami sering dijadikan sebagai pembanding untuk menilai perubahan ke bentuk ekosistim lain.

Bahan organik tanah dapat dijadikan sebagai salah satu indeks dalam menentukan kualitas tanah dan sustainability (Lerson dan Pierce, 1991). Bahan organik tanah sangat nyata mempengaruhi berbagai parameter tanah.
Bahan organik tanah secara simultan juga merupakan sumber hara tanaman, secara fisika dan kimia akan memfasilitasi terbentuknya agregat dan struktur tanah, meningkatkan kandungan air tanah, sumber energi bagi biota tanah, dan selanjutnya akan berpengaruh terhadap proses biologi di dalam tanah.

Kandungan bahan organik tanah sangat ditentukan oleh keseimbangan antara faktor-faktor yang mempengaruhi pembentukan-nya dan faktor yang mempengaruhi proses pelapukannya. Faktor pembentuk meliputi jumlah dan kualitas dari sumber bahan organik, sedangkan faktor pelapukan ditentukan oleh kondisi yang mempengaruhi kecepatan oksidasi dari bahan organik tersebut. Pada daerah tropik umumnya perubahan dari ekosistim hutan ke lahan pertanian akan menurunkan kandungan bahan organik tanah ke tingkat keseimbangan yang rendah (Woomer dan Ingram, 1990; Guggenberger et al., 1994; 1995). Jumlah kehilangan bahan organik tanah tersebut bisa mencapai 20 sampai 50 $\%$. 
Penurunan kandungan bahan organik disebabkan oleh beberapa aspek, antara lain faktor erosi yang akan menghanyutkan bahan organik dan tanah lapisan atas yang kaya bahan organik (Woomer dan Ingram, 1990). Namun demikian, perubahan bahan organik tanah pada tanah yang tidak tererosi sangat dipengaruhi oleh kondisi fisika, kimia, dan biologi tanah.

Menurut Nye dan Greenland (1960) dan Sanchez (1976) disamping jumlah penambahan bahan organik, kelembaban dan temperatur juga berperan penting dalam menentukan tingkat bahan organik tanah. Oleh karena itu perubahan kondisi tanah dengan berbagai manipulasi praktek pertanian seperti pengolahan tanah, pemupukan dan pengapuran akan dapat meningkatkan kandungan bahan organik tanah ke level tertentu, karena bahan organik tanah merupakan bahan yang dapat diperbaharui.

Yasin (2004) telah melakukan penelitian tentang penggunaan berbagai lahan di Kabupaten Dharmasraya, terutama penggunaan-nya untuk tanaman perkebunan. Namun demikian, belum banyak penelitian terhadap degradasi pada lahan kebun campuran dan tegalan. Sehingga, dirasa perlu melakukan penelitian degradasi lahan pada kondisi lahan tersebut.

Penelitian ini bertujuan untuk melihat degradasi lahan pada lahan kebun campuran dan tegalan..

\section{BAHAN DAN METODE}

Penelitian telah dilaksanakan di Kecamatan Sungai Rumbai Kabupaten Dharmasraya dan di Laboratorium Jurusan Tanah Fakultas Pertanian Unand. Sampel tanah diambila dari lima jenis penggunaan lahan, yaitu: hutan, tegalan, semak belukar, alang-alang, dan kebun campuran. Pada setiap jenis penggunaan lahan diambil sampel tanah sedalam $20 \mathrm{~cm}$ dengan bor Belgia secara komposit sebanyak 4 ulangan. Pada setiap ulangan dilakukan pengambilan sub-sampel sebanyak 5 tempat dengan jarak 5 sampai $20 \mathrm{~m}$. Kelima subsampel diaduk merata menjadi satu sampel komposit. Sampel komposit ini kemudian dikeringkan, diayak dengan ayakan $2 \mathrm{~mm}$, dan selanjutnya digunakan untuk analisis.

Analisis sifat kimia tanah, hanya dibatasi terhadap nilai $\mathrm{pH}$, Kandungan $\mathrm{C}$ organik, N, P, dan K tanah. Sedangkan sifat fisika tanah hanya terbatas pada nilai Berat Volume (BV) Tanah.

\section{HASIL DAN PEMBAHASAN}

Nilai Berat Volume Tanah dan Beberapa Sifat Kimia Tanah

Berat volume tanah dan beberapa sifat kimia tanah pada berbagai jenis penggunaan lahan tanaman perkebunan dapat dilihat pada Tabel 1.

Tabel 2. Beberapa parameter sifat kimia dan nilai BV tanah dari berbagai jenis penggunaan lahan di Kecamatan Sungai Rumbai Kabupaten Dharmasraya,

\begin{tabular}{lcccccc}
\hline $\begin{array}{c}\text { Penggunaan } \\
\text { lahan }\end{array}$ & $\begin{array}{c}\text { Berat } \\
\text { volume } \\
\left(\mathrm{g} / \mathrm{cm}^{3}\right)\end{array}$ & $\begin{array}{c}\mathrm{C}- \\
\text { Organik }\end{array}$ & $\begin{array}{c}\mathrm{pH} \\
\mathrm{H} 2 \mathrm{O}\end{array}$ & $\mathrm{pH} \mathrm{KCL}$ & $\begin{array}{c}\text { Al-dd } \\
(\mathrm{me} / 100 \\
\mathrm{g})\end{array}$ & $\begin{array}{c}\text { Kejenuhan } \\
\mathrm{Al}(\%)\end{array}$ \\
\hline & & & & & & \\
Hutan & $0,87 \mathrm{c}^{*}$ & $2,91 \mathrm{a}$ & $4,75 \mathrm{a}$ & $4,61 \mathrm{~b}$ & $4,22 \mathrm{a}$ & $53,98 \mathrm{a}$ \\
Tegalan & $1,15 \mathrm{a}$ & $1,92 \mathrm{~b}$ & $5,41 \mathrm{a}$ & $5,0 \mathrm{a}$ & $1,52 \mathrm{~b}$ & $39,10 \mathrm{a}$ \\
Semak belukar & $0,87 \mathrm{c}$ & $2,19 \mathrm{~b}$ & $4,84 \mathrm{a}$ & $4,59 \mathrm{~b}$ & $4,05 \mathrm{a}$ & $57,49 \mathrm{a}$ \\
$\begin{array}{l}\text { Alang-alang } \\
\begin{array}{l}\text { Kebun } \\
\text { campuran }\end{array}\end{array}$ & $1,04 \mathrm{ab}$ & $2,10 \mathrm{~b}$ & $5,37 \mathrm{a}$ & $4,90 \mathrm{ab}$ & $1,91 \mathrm{~b}$ & $39,84 \mathrm{a}$ \\
& $0,99 \mathrm{bc}$ & $2,17 \mathrm{~b}$ & $5,44 \mathrm{a}$ & $5,04 \mathrm{a}$ & $1,18 \mathrm{~b}$ & $31,85 \mathrm{a}$ \\
\end{tabular}

* Angka yang diikuti oleh huruf kecil yang sama pada kolom yang sama menunjukkan berbeda tidak nyata menurut BNT 5\% 
Rendahnya nilai BV tanah pada semak belukar dan kebun campuran dari tegalan dan alang-alang nampaknya berhubungan dengan pengembalian bahan organik yang lebih banyak pada lahan semak belukar dan kebun campuran yang dicirikan oleh tingginya kandungan C-organik tanah. Bahan organik dapat meningkatkan partikelpartikel tanah sehingga tanah menjadi gembur dan menyebabkan ruang pori lebih banyak. Keadaan inilah yang menyebabkan BV menjadi rendah. Buckman dan Brady (1982) menyatakan bahwa bila kandungan bahan organik tinggi, maka proses pembutiran tanah permukaan berlangsung baik. Pembutiran tanah menyebabkan keadaan tanah menjadi longgar dan berporipori akibatnya $\mathrm{BV}$ menjadi rendah.

Nilai BV yang tertinggi terdapat pada tegalan $\left(1,15 \mathrm{~g} / \mathrm{cm}^{3}\right)$. Hal ini berhubungan dengan praktek budidaya yang dilaksanakan. Disamping tidak adanya usaha pengembalian bahan organik ke tanah, faktor pengolahan tanah yang intensif juga merupakan salah satu faktor penyebab meningkatnya nilai BV tanah. Adapun mekanismenya yakni pengolahan tanah akan menciptakan keadaan yang sangat ideal bagi mikroorganisme untuk merombak bahan organik sehingga ketersediaannya cepat berkurang, dan menyebabkan tanah menjadi padat. Hal ini senada dengan pendapat Buckman dan Brady (1982) bahwa pengolahan tanah yang intensif akan menaikkan BV tanah.

Pengalihfungsian hutan ke penggunaan lahan lainnya telah menyebabkan peningkatan BV tanah pada tegalan (24\%), alang-alang (15\%), kebun campuran $(10 \%)$, serta semak belukar $(<1 \%)$ bila dibandingkan dengan ekosistem hutan.

\section{C-Organik Tanah}

Pada Tabel 1 terlihat bahwa keempat penggunaan lahan mempunyai kandungan C-organik berbeda nyata dengan hutan dan secara angka-angka dari keempat penggunaan lahan lainnya. Hal ini jelas berhubungan dengan pengembalian bahan organik berupa daun dan ranting ke permukaan tanah, namun demikian karena jumlah populasi dan keragaman pada lahan semak belukar lebih sedikit dari hutan menyebabkan jumlah kandungan $\mathrm{C}$-organik pada lahan ini masih dibawah ekosistem hutan

Kandungan C-organik kebun campuran lebih tinggi dibandingkan lahan alang-alang dan tegalan disebabkan juga oleh keragaman vegetasi pada kebun campuran lebih banyak dibandingkan dengan kedua lahan ini. Sedangkan untuk lahan tegalan yang ditanami tanaman semusim yakni jagung, kedelai, dan ubi kayu hampir semua bagian tanaman terbawa panen. Sehingga bahan organik yang dikembalikan ke tanah sangat sedikit serta ditambah dari efek pengolahan tanah yang intensif. Rusman (1991) menyatakan bawa, pengolahan tanah yang intensif akan mempercepat penurunan kandungan bahan organik tanah karena pengolahan tanah merubah keadaan porositas yang dapat memperbaiki tata udara tanah. Dengan terjaminnya peredaran udara dalam tanah akan dapat meningkatkan aktifitas mikroorganisme tanah yang diperlukan untuk perombakan sumber bahan organik.

Berdasarkan hasil analisis pada Tabel 1 dapat dinyatakan bahwa akibat alih fungsi lahan yakni dari hutan menjadi berbagai penggunaan lainnya telah menyebabkan terjadinya penurunan kandungan C-organik tanah pada semak belukar (24\%), kebun campuran (24\%), alang-alang (28\%), serta tegalan $(34,5 \%)$ bila dibandingkan dengan ekosistem hutan. Hal ini sesuai dengan apa yang dikemukakan oleh Sombroek et al (1993) bahwa perubahan ekosistem hutan tropik ke berbagai bentuk penggunaan lahan pertanian akan dapat menyebabkan kehilangan C-organik tanah sebesar 20-50\%.

\section{pH, Al-dd, dan Kejenuhan Al}

Secara statistik nilai Al-dd pada penggunaan lahan hutan dan semak belukar berbeda tidak nyata dan berbeda nyata dengan lahan alang-alang, kebun campuran, serta tegalan. Bila dibandingkan secara angka-angka, maka nilai tertinggi diperoleh pada penggunaan lahan hutan $(4,22 \mathrm{me} / 100$ g) dan yang terendah pada kebun campuran $(1,18 \mathrm{me} / 100 \mathrm{~g})$. Sedangkan nilai kejenuhan 
Al tidak berbeda nyata untuk semua penggunaan lahan.

Tingginya Al-dd pada hutan berhubungan dengan nilai $\mathrm{pH}$ tanah yang rendah. Menurut Jordan (1985) bahwasanya hutan tropik mempunyai reaksi tanah yang masam dan $\mathrm{Al}$ merupakan kation yang dominan pada lapisan atas $(0-20 \mathrm{~cm})$ karena kation-kation basa mengalami leaching secara intensif ke lapisan bawah.

Masih tingginya kejenuhan Al pada lahan yang telah diberi kapur yakni tegalan, kebun campuran, serta alang-alang dipengaruhi oleh waktu pemberian kapur tersebut. Dimana pada ketiga lahan ini telah diberi kapur pada tahun 1984 untuk tegalan dan alang-alang sedangkan untuk kebun campuran dilakukan pada tahun 1990. Dengan demikian, diyakini efek sisa dari kapur tersebut sedikit. Hal ini diperkuat dari hasil penelitian Yasin (1991) yang menemukan bahwa setelah tiga tahun dari pemberian pertama kapur, nilai kejenuhan Al masih tidak terukur. Namun setelah lima tahun dari pemberian pertama kejenuhan $\mathrm{Al}$ meningkat menjadi 29\%. Tisdale dan Nelson (1975) menjelaskan, pemberian kapur ke dalam tanah dapat dirasakan manfaatnya selama tiga sampai empat tahun setelah pemberian pertama.

Nilai $\mathrm{pH}$ yang tinggi pada tegalan dan kebun campuran $(5,41$ dan 5,44) nampaknya berhubungan dengan praktek budidaya pertanian yang telah dilaksanakan. Kedua lahan ini pernah diberi kapur pada tahun 1984 (tegalan) dan tahun 1990 (kebun campuran) masing-masing sebanyak 2 ton/ha. Input ini menyebabkan peningkatan $\mathrm{OH}^{-}$dan menurunkan daya larut $\mathrm{Al}$ dan $\mathrm{Fe}$ sehingga $\mathrm{pH}$ tanah meningkat.
Paling rendahnya $\mathrm{pH}$ tanah pada ekosistim hutan (4,75) disebabkan oleh kandungan $\mathrm{Al}$ yang juga tinggi. Kandungan Al yang sangat tinggi dalam larutan tanah merupakan penyebab kemasaman tanah karena ia cenderung terhidrolisis menghasilkan ion hidrogen yang akhirnya menyebabkan nilai $\mathrm{pH}$ rendah. Alumunium merupakan sumber utama ion hidrogen dalam sebagian tanah masam. Sesuai dengan pernyataan Jordan (1985) bahwa hutan tropik mempunyai reaksi tanah yang masam dan alumunium merupakan kation yang dominan karena leaching yang terjadi secara intensif.

Nilai $\mathrm{N}$ dan $\mathrm{P}$ ekosistem hutan lebih tinggi dari ke empat penggunaan lahan lainnya (Tabel 2). Hal ini disebabkan oleh keragaman hayati yang terdapat pada ekosistem hutan sehingga ada pengembalian bahan organik ke tanah berupa ranting, daun, mikroorganisme, dan binatang yang mati yang terjadi secara alami. Fenomena ini menunjukkan bahwa bahan organik adalah sebagai penyumbang unsur hara tanaman (Larson dan Pierce, 1991). Pengaruh tidak langsung dari ekositem hutan adalah pada proses dekomposisi bahan organik. Proses ini akan menghasilkan asam-asam organik yang mampu menekan aktivitas kationkation pengikat fosfat seperti $\mathrm{Al}$ dan $\mathrm{Fe}$.

Menarik untuk diperhatikan pada Tabel 2 yakni relatif tingginya kandungan kedua unsur ini pada lahan tegalan dan kebun campuran dibandingkan dengan penggunaan lahan semak belukar serta alang-alang dan hampir mendekati kandungan N, P hutan. Hal ini adalah akibat

Tabel 2. Kandungan $\mathrm{N}$ total dan $\mathrm{P}$ tersedia tanah dari berbagai jenis penggunaan lahan di Kabupaten Dharmasraya, Sumatera Barat.

\begin{tabular}{lcc}
\hline Penggunaan lahan & N- total $(\%)$ & P- tersedia $(\mathrm{ppm})$ \\
\hline Hutan & $0,15 \mathrm{a}$ & $8,91 \mathrm{a}$ \\
Tegalan & $0,14 \mathrm{a}$ & $8,80 \mathrm{a}$ \\
Semak belukar & $0,14 \mathrm{a}$ & $6,73 \mathrm{a}$ \\
Alang-alang & $0,10 \mathrm{a}$ & $8,71 \mathrm{a}$ \\
Kebun campuran & $0,13 \mathrm{a}$ & $8,33 \mathrm{a}$ \\
\hline
\end{tabular}

* Angka-angka yang diikuti oleh huruf kecil yang sama pada kolom yang sama menunjukkan berbeda tidak nyata menurut BNJ 5\%. 
dari pemupukan dilakukan pada tegalan. Pemupukan yang telah diberikan pada lahan ini adalah Urea dengan dosis $150 \mathrm{~kg} / \mathrm{ha}$, TSP 100 kg/ha, KCl 50 kg/ha. Untuk kebun campuran Urea diberikan $1 \mathrm{~kg} / \mathrm{batang}$, TSP $1 \mathrm{~kg} / \mathrm{batang}$ dan $\mathrm{KCl} 0,5 \mathrm{~kg} / \mathrm{batang}$. Hal ini menunjukkan bahwa penambahan input berupa pupuk buatan mampu mempertahankan kandungan $\mathrm{N}$ dan $\mathrm{P}$ tanah.

Rendahnya kandungan unsur $\mathrm{P}$ pada lahan semak belukar disebabkan oleh $\mathrm{pH}$ tanah yang rendah yakni 4,84 sehingga menyebabkan P kurang tersedia. Se makin rendah $\mathrm{pH}$ tanah, maka akan semakin besar pula konsentrasi $\mathrm{Al}$ dan $\mathrm{Fe}$. Hal ini akan mengakibatkan besar pula jumlah $\mathrm{P}$ yang diikat. Sesuai dengan pendapat Nyakpa et al (1988) bahwa ketersediaan $\mathrm{P}$ akan menurun bila $\mathrm{pH}$ tanah lebih rendah dari 5,5 karena terjadinya serapan $\mathrm{P}$ oleh ion $\mathrm{Al}$ dan $\mathrm{Fe}$.

\section{KESIMPULAN}

Dari hasil penelitian tersebut dapat disimpulkan bahwa penggunaan lahan kebun campuran memiliki kandungan $\mathrm{C}$ organik lebih tinggi dan $\mathrm{BV}$ tanah lebih rendah dibandingkan dengan lahan tegalan.

\section{DAFTAR PUSTAKA}

Buckman, O.H. dan Brady, N.C. 1989. Tahune nature and properties of soil. New York. Macmilan. Publishing Company.

Hakim, N. 1984. Pengaruh sisa pengapuran terhadap produksi jagung pada tanah Podzolik Sitiung II. 51-57 hal.

Hakim, N. Agustian dan Yasin, S. 1989. Input terpadu untuk meningkatkan produksi tanaman pangan di lahan kering. Fakultas Pertanian. Universitas Andalas. Padang. 30 hal.

Jordan, F. 1985. Nutrient cycling in tropical forest ecosystem. John Willey Sons. New York.

Rusman, B. 1999. Konservasi tanah dan air. Fakultas Pertanian. Universitas Andalas. Padang. 182 hal.

Sanchez, PA. 1993. Sifat dan pengelolaan tanah tropika. Penerbit ITB. Bandung. 51-52 hal.

Tan, KH. 1998. Dasar-dasar kimia tanah. Gajah Mada University Press. Yogyakarta.

Thompson, L. M. and F.R. Troch. 1978. Soil and soil fertility. M.C. GrawHill Book Company. New York.

Yasin, S. 1991. Kajian sifat kimia tanah ultisol Sitiung IV setelah 5 tahun pengelolaan. Universitas Andalas. Padang. 30 hal.

Yasin, S. 2001. Water and nutrient budget under a tropical montane forest in tahune Soutahun Ecuadorian Andes. Journal Bayreuther Boden kunliche Berichte Deutchland. 199 hal. 